\title{
Protesoptogte en die rol van die Nederduitsch Hervormde Kerk
}

\author{
I W C van Wyk \\ Universiteit van Pretoria
}

\begin{abstract}
Protest marches and the role of the Nederduitsch Hervormde Church

This article deals with the phenomenon of protest against the state. The fact that resistance and protest have always been part of social reality is pointed out. For this reason the state, particulary a democratic state, should provide scope for legitimate protest and protest marches. However, protest marches are not a magic formula for bringing about justice. Protest marches themselves are an extremely ambivalent matter. It is the responsibility of the church to guide the people and the nation in such a way that they will strive for attainable ideals within the bounds of possibility.
\end{abstract}

\section{INLEIDING}

Verset teen die staat en die een openbare gestalte daarvan, naamlik protesoptogte, is vandag ' $n$ uiters aktuele saak in Suid-Afrika. Dit is nie net meer mense van links wat oproep tot verset en weerstand teen die staat nie, maar in die jongste tyd ook mense van regs. Nie net meer groepe van links nie, maar ook groepe van regs marsjeer die strate af om op hierdie wyse aan te dring op hulle regte en voorkeure.

Dit is nie wenslik om uitspraak te lewer, mening te vorm en aanbevelings te doen oor 'n saak soos protesoptogte, sonder 'n omvattende teorievorming oor die verhouding van staat en kerk en die daarmee samehangende visie van die rol van die kerk in die maatskappy nie. Ek wil in hierdie artikel probeer om vanuit 'n breë teoretiese raamwerk enkele riglyne aan te bied vir die kerk se spreke en rol in die nuwe politieke kultuur wat blyk gevestig te raak. 
Protesoptogte is in die Hervormde Kerk 'n nuwe onderwerp. Die beleidstuk Kerk en Wêreld 2000 wat deur die Algemene Kerkvergadering van 1986 as breë strategie vir die Kerk se spreke en optrede in sosiaal-politieke probleme aanvaar is, kon nog nie aan sulke probleme aandag gee nie, aangesien protesoptogte toe nog nie gewettig was nie. Die Herderlike Skrywe van 1990 bet ook nie aan protesoptogte as 'n vorm van verset aandag gegee nie. In die lig van hierdie situasie moet daar begin word om teologies oor hierdie sosiaal-etiese temas na te dink. Dit is ook belangrik dat die Hervormde Kerk dit vinnig sal doen aangesien die meeste ander (nie-Afrikaanse) kerke alreeds daaroor nagedink bet en op een of ander wyse alreeds daarby betrokke is (vgl hiervoor o a Villa-Vicencio 1990). Die Hervormde kerk mag nie rondom sosiaal-politieke sake totaal irrelevant raak nie.

\section{DIE BYBEISE VISIE VAN DIE STAAT, WEERSTAND EN PROTES}

\subsection{Ou Testament}

\subsubsection{Prediker}

Die boek Prediker, wat op die eeue-lange ervarings van die Jodedom en op die insigte en wyshede van geslagte mense gebaseer is, skets aan ons die werklikhede rondom state, regerings, konings en hulle onderdane (vgl Von Rad 1970:292-306; Michel 1988:66-75, 82-94).

Die outeur van die boek Prediker weet van die feit dat maghebbers in grootheidswaan te lank aan die mag wil vashou, nie na die raad van raadgewers wil luister nie en so weersin en weerstand teen hulle laat opbou, totdat die 'onderdruktes' hulle eie leier aan bewind stel, met dikwels skadelike gevolge (vgl Pred 4:13-16). Dit is wat feitelik gebeur. In toestande van armoede, onreg en ongeregtigheid word die gesag van 'n staat verwerp en 'n nuwe persoon of groep bekom die mag om te regeer. Insiggewend is egter dat die Predikerboek tog nie belangstel om 'n 'bevrydingsteologie' te verkondig nie. Net soos Paulus sien by die noodsaak daarvan in dat dit tot almal se voordeel is dat elkeen aan die koning onderdanig sal bly ten spyte van die feit dat die koning se mag op oneerbare maniere beveilig word (vgl Pred 5:7-8). Dit is vir die Prediker meer wys om nie die koning se gesag uit te daag nie. Hy het die mag en hy tree na goeddunke op. Verder lê die gelowige 'n eed van getrouheid voor God af en op grond daarvan moet hy gehoorsaam bly (vgl Pred 8:2-5). Die Prediker weet uit sy ervaring dat maghebbers van hulle trone gestoot word, maar weet ook van die tragiese gevolge wanneer 'n slaaf koning word (vgl Pred 10:16), met ander woorde wanneer inkompetente martelaarsfigure die staatsadministrasie oorneem.

Die outeur van Prediker is 'n groot realis. Hy weet dat dit in die beste belang van 'n land is wanneer die bevolking die koning gehoorsaam, hoe korrup hy ook al 
mag wees. Dit is op die ou einde beter dat hy, eerder as 'n inkompetente 'simbool van die bevrydingstryd' regeer. Tog weet hy aan die ander kant, dat regerings en maghebbers ten spyte van vermanings, onttroon word deur die armes en verontregtes. Hierdie tweeledigheid kenmerk die mensheidsgeskiedenis.

Daar kan gekonkludeer word dat hierdie boek van die feitelikheid uitgaan dat die wêreldgeskiedenis deur mag - opstand/omverwerping - en onderdrukking gekenmerk word. Weerstand en protes is dus geen nuwighede nie. Dit is deel van die werklikheid van hierdie wêreld. Die kerk sal dit as sy basiese vertrekpunt moet neem.

\subsection{Nuwe Testament}

Die Nuwe-Testamentiese staatsbeskouing konsentreer op die sosiaal-etiese oproep tot gehoorsaamheid aan die staat (vgl veral Wendland 1975:72-76; Schrage 1982:107-115, 226-230; Lohse 1988:84-88). In hoeverre hierdie eis gehoorsaam behoort te word, is 'n omstrede saak.

Ten einde hierdie vraag te beantwoord, konsentreer ons op die bekende Romeine 13:1-7. Hiedie perikoop het in die verlede en speel vandag nog 'n belangrike rol wanneer vasgestel moet word wat die oorsprong, taak en gesag van die owerheid is, maar ook veral wanneer vasgestel moet word wat die houding van die Christen teenoor die owerheid moet wees (vgl Wilckens 1982:43-66). Hierdie perikoop kom gewoonlik onder die soeklig wanneer onderdane van 'n bepaalde owerheid ernstige besware teen dié owerheid uiter of demonstreer en veral dán, wanneer 'n revolusie of burgeroorlog dreig. Die regeringsgesindes kan en sal altyd met groot oortuiging op Romeine 13 terugval, terwyl die regeringsteenstanders sal rondskrop om te verduidelik dat wat daar staan nie so bedoel word nie, of dat dit ook anders verstaan kan word.

Die rede waarom hierdie perikoop so 'n hindernis sal bly, is voor die hand liggend. Alhoewel daar ook in Titus 3:1, 1 Petrus 2:13, Mark 12:13-17 en 1 Timoteus 2:2 die eis tot onderwerping aan die owerheid voorkom, is dit slegs hier dat met betrekking tot die owerheid gesè word dat daar geen gesag ( $\dot{\xi}$ ovoi $\alpha$ ) is wat nie van God kom nie (vgl egter Joh 19:11), en dat die bestaande owerheid daar is deur die beskikking van God. In lyn hiermee word die verdere stelling dan gemaak dat wie hom teen die owerheidsgesag verset, in opstand kom teen die ordening ( $\delta \alpha \tau \alpha \gamma \dot{)})$

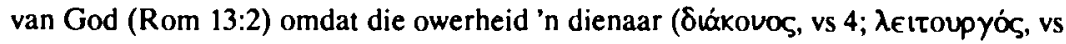
6) van God is. Hier word dus ongekwalifiseerd gesê dat indien iemand hom teen die owerheidsgesag verset, hy hom in feite teen God verset. Wilckens (1982:40) sien geen ander keuse nie as om te sê: 'Paulus mahnt zum Gehorsam generell und ohne Einschränkung oder Ausnahme.' Al die eksegetiese probleemvrae (vgl Pelser 1986: 
516-524) sal hierdie uitspraak en konklusie van Wilckens nie in diskrediet kan bring nie.

Volgens Pelser (1986:526-528) kom die basiese aansprake van die teks op die volgende neer:

* Ons het nie hier met 'n teologies-metafisiese of natuurregtelike begronding van die staat te doen nie. Wat hier van die staat gese word, het niks met 'skeppingsordeninge' te maak nie. Waarom dit wel handel, sê Hultgren (1976:267) treffend: 'Rather than affirming a "Christological foundation of the state", Paul calls for a "Christological foundation of citizenship", which is addressed to the individual Christian'. Die owerheid word nie hier aangespreek nie, maar wel die gelowiges (in die eerste instansie) en tog ook elke mens (vgl Wilckens 1982:39).

* Die onderworpenheid wat hier geëis word, is inderdaad radikaal en word met 'n 'ordening' van God begrond. Die werkwoord unotáoow wat hier gebruik word, druk die gedagte uit van 'n daargestelde orde waarvan die minagting tot die versteuring van die lewe van die gemeenskap lei (vgl Käsemann 1974:336; Schlier 1979:387). Hierdie eis geld te alle tye en onder alle omstandighede. Paulus het hierdie eis gestel wel bewus van die feit dat die Romeinse owerheid 'n heidense owerheid was wat talle gruweldade begaan het. Hy evalueer nie die bestaande owerheid nie. Dit gaan vir hom slegs om 'n prinsipiële saak, ongeag hoe die bepaalde staatsbestel daar uitsien.

- Die prinsipiële begronding van die eis tot onderworpenheid in vers 1 word in vers 5 gerugsteun deur ' $n$ beroep op die gewete. ouvewీ́no menslike gewete in die algemeen (Pelser 1986:528). Onderworpenheid aan die owerheid moet dus vir almal, Christen en heiden, 'n gewetensaak wees.

* Onderworpenheid en gehoorsaamheid aan die owerheid sal egter ook afgedwing word deur middel van straf vir die ongehoorsames (Rom 13:4, 5).

2.2.1 Romeine 13 teen die agtergrond van weerstand, geweldlose verset en die reg tot protes

'n Belangrike probleem ten opsigte van Romeine 13 is dat die outeur nie aandui dat daar sekere omstandighede sou kon wees waaronder weerstand teen die owerheid geregverdig sou kon word nie. Deur 'n onderskeid te maak tussen hulle wat de facto regeer en die gesag as 'n prinsiep wat daar is vir die beswil van die publiek, of dan die persone wat regeer en die gesag as sodanig, is nie vanuit die teks toelaatbaar nie (vgl Hultgren 1976:267). Die ou vraag bly dus: Mag mense hulle teen 'n tiranieke owerheid verset? Op hierdie vraag is geen eenduidige antwoord moontlik nie. Pelser (1986:530-532) het reg as hy op grond van Romeine 13 sê dat die minste wat van elke burger verwag kan word, is om nie die bestaande (?) orde te versteur, 
as hy nie 'n beter een in die plek daarvan kan stel nie. Onder geen omstandighede mag een euwel met 'n ander euwel vervang word nie. Die basiese eis van Romeine 13 bly dus die verantwoordelikheid vir die handhawing van die orde en die bestryding van die anargie. Daarmee word nie gesê en mag nie gesê word dat die bestaande (!) orde (gewelddadig) gehandhaaf moet word nie. Die orde kan in sekere gevalle juis bevorder word deur die bestaande orde struktureel te verander. Die teenoorgestelde geld natuurlik ook en dit moet weer gesê word. Die bestaande orde mag ook nie vervang word met die wêreldvreemde utopie van revolusionêres of die romantieke droom van tradisionaliste nie. Chaos sal losbars as daar aan die eise van sulke minderheidsgroepies toegegee word. Daarom kan 'n mens jou nie 'n samelewing voorstel sonder die eis van Romeine 13 nie. As hierdie eis nie die basiese sosiaal-etiese riglyn bly nie, sal geen samelewing geordend kan voortbestaan nie. Maar weer eens: Dit beteken nie 'n kritieklose en slaafse navolging van 'n bepaalde staatsbestel nie. Pelser (1986:531) vat dit pragtig saam:

Hy [d i Rom 13] moet streng gesproke as struikelblok in die pad bly lè, nie as koue, uitgediende dogma nie, maar as waarborg dat indien daar vir fisiese of gewelddadige optrede teen die owerheid gekies word, dit werklik die laaste en enigste uitweg sal wees. Dit moet dus altyd die kritiese vraagteken bly wat oor alle optrede hang. Dit moet onvermydelik die gevolg hê dat alle optredes vir dié wat enigsins 'n gewete het, 'n gewetensaak sal wees.

'n Verdere probleem met Romeine 13 is dat die magstrukture van vandag - minstens in 'n demokratiese bestel - ingrypend verskil van die Romeinse magstrukture. Die onderdane self kies 'n regering. Hulle kan hulle op grondwetlike wyse teen 'n owerheid verset en hulle kan by 'n verkiesing die mag ontneem. Die onderdane het in baie gevalle die geleentheid om deur middel van die parlement, komitees, vakbonde en organisasies invloed op die regeerders uit te oefen om na griewe en probleme te luister en daaraan aandag te gee. Binne 'n demokrasie word daar juis geleentheid gebied vir vreedsame protes, met die bedoeling om aan mense en groepe die geleentheid te bied om die regeerders en die bevolking in te lig oor onreg en ongeregtighede. Die verwagting hiermee is dat die moontlikheid van gewelddadige protes en revolusie sal afneem. Die ruimte vir vreedsame verandering en selfs magswisseling, ten behoewe van reg, geregtigheid en orde word vergroot. Vreedsame protes as hoeksteen van die demokrasie, stel die Bybelse opdrag van gehoorsaamheid aan die owerheid dus nie in gevaar nie, maar bevorder eerder die moontlikheid van langdurige en gewillige onderdanigheid aan die owerheid. Die veranderde staatsbestel verander niks aan die opdrag van Romeine 13 nie. Binne 'n de- 
mokrasie kan daar net met groter gemak en met minder persoonlike wrokgevoelens aan hierdie perikoop gehoor gegee word.

As konklusie kan gesê word dat Romeine 13 se eis tot gehoorsaamheid aan die staat onverkort gehandhaaf moet word. Tog weet ons onder andere vanuit die wysheidsliteratuur dat die mensdom onder sekere omstandighede hierdie bevel eenvoudig verontagsaam, met al die konsekwensies daaraan verbonde. Die moderne demokratiese bestel stel Romeine 13 hoegenaamd nie in gevaar nie. Trouens, die moontlikheid om hieraan langdurige uitvoering te gee, word juis deur 'n demokrasie verseker. Die toelating van kritiek, protes en selfs magswisseling maak die gehoorsaamheid aan Romeine 13 juis makliker.

Gehoorsaamheid aan die staat kan egter slegs dan verseker word wanneer daar ruimte aan onder andere die kerk(e) gegee word om die staat te vermaan oor die stand van reg en geregtigheid.

\section{DIE OWERHEID, REG EN GEREGTIGHEID EN DIE PROFETIESE VERMANINGS VAN DIE WYSES}

\subsection{Die wyses se profesie}

Die bedoeling van die Spreukeboek is om mense te leer om in wysheid te onderskei tussen verstandigheid en onverstandigheid en hulle 'n opvoeding te gee waardeur hulle ' $n$ sin vir regverdigheid, reg en billikheid sal ontwikkel (vgl Spr 1:2-3). Geregtigheid, reg en billikheid is dus volgens die Bybel, van die mees basiese menslike waardes wat aangeleer moet word. Dit is waardes waarop 'n staatsbestel gebaseer behoort te word. Hierdie gedagtes en motiewe word in verwante literatuur vollediger uitgewerk. Ek verwys na 'n enkele voorbeeld naamlik Psalm 72.

Psalm 72 handel oor die regeertaak van die koning/owerheid. Hier word duidelik uitgestippel wat van die koning verwag word, wat die basis van sy beleid moet wees en watter aspekte van sy regeertaak voorrang moet geniet. Hierdie is egter ideale waarna gestrewe moet word en is ongelukkig nie werklikhede nie. In hierdie Psalm word gebid dat die koning al hierdie dinge sal doen, want hy doen dit nie (vg! Kraus 1972:493-500): Hy moet die reg handhaaf (vs 1 ), hy moet regverdige beslissings vel (vs 2), aan die verdruktes reg laat geskied (vs 2), die reg van die verdruktes beskerm (vs 4), die armes te hulp kom (vs 4), hom oor die swakke en behoeftige ontferm (vs 13), hulle van onderdrukking en geweld bevry (vs 14) en hulle lewens as kosbaar ag (vs 14), met ander woorde die menseregte handhaaf.

Die koning/owerheid het dus volgens die Skrif die verantwoordelikheid om so te regeer dat reg en geregtigheid in stand gehou en bevorder word en die belange en menswees van die minderbevoorregtes en mindergegoedes beskerm $\mathrm{kan}$ word. Hierdie waardes geld nie as slim maniere om die mag te behou nie, maar as opdrag 
van God. Daarom moet die regering/koning oor hierdie sake vermaan word. Hier lê die profetiese roeping van die kerk. Die profetiese taak van die kerk konsentreer dus in die eerste instansie op vermanings.

Prediker het al die wysheid oorgelewer dat ' $n$ jong man wat arm is maar verstandig beter (is) as 'n koning wat oud is maar dwaas en hom nie meer wil laat waarsku nie (Pred 4:1). Verder staan daar: Dit is beter om vermaan te word deur iemand wat wysheid het, as om besing te word deur' $n$ dwaas (Pred 7:5).

Die manier van vermaning is egter van groot belang waarop deeglik gelet moet word. Die Spreukeboek kom met groot wysheid na vore: Met geduld kan iemand in ' $n$ magsposisie tot ander insigte gebring word; met ' $n$ versigtige benadering word weerstand afgebreek (Spr 25:15). Daarom word tereg gewaarsku: Dien die Here, my seun, en ook die koning; moet jou nie ophou met oproermakers nie. Hulle ondergang kom skielik; niemand weet wanneer die Here en die koning hulle vernietig nie (Spr 24:2122).

Samevattend kan gemeld word dat die wysheidsliteratuur duidelik 'n baie gebalanseerde benadering na vore bring. Enersyds sien hierdie skrywers die noodsaak daarvan in dat regeerders vermaan moet word oor die stand van reg en geregtigheid, andersyds besef hulle dat hierdie vermanings baie versigtig, omsigtig en sonder openbare uittarting moet geskied indien die vermaners sukses wil behaal. Diplomatiese vermanings sonder oproer is die resep vir sukses. Maar wee hom wat nie luister nie! Hy moet probleme verwag, nie net van mense nie, maar ook van God.

3.2 Die profete se wysheid: Reg en geregtigheid bewaar van die oordeel van God Dit was veral die profete wat daarop aangedring het dat die regeerders moet toesien dat reg en geregtigheid instand gehou en bevorder word. Hulle het trouens die oordeel van God oor 'n sodanige ongehoorsaamheid afgekondig. Die oordeel van God sou sig voltrek in ondergang van die staat en in God se afwesigheid in die samelewing (vgl Pannenberg 1984:23-24 vir verdere sistematiese aspekte van hierdie onderwerp).

Amos het, nadat hy die oordeel van God oor die vyande van Israel uitgespreek het (Amos 1:3-2:16), die sondes van Israel uitgewys en gewaarsku dat hulle deur middel van aardbewings (Amos 2:13vv) en plunderaars (Amos 3:11) gestraf sal word. Die sondes waarna verwys word, konsentreer hoofsaaklik om ekonomiese uitbuiting en selfverryking ten koste van die swakkeres (vgl o a Amos 5:11; 6:4-8; 8:48).

Miga profeteer ook teen die ekonomies-maatskaplike uitbuiting en benadeling van die swakkeres (vgl bv Miga $2: 1-3 ; 8 ; 9$ ) en dreig dan dat die Here hulle nie sal 
antwoord as hulle na Hom roep nie en Hom nie aan hulle sal openbaar nie, omdat hulle verkeerd gehandel het (Miga 3:1-4).

Die profete het geweet dat daar sonder geregtigheid nie vrede en heil vir die individu en vir die gemeenskap kan wees nie. Waarop dit by die profete aankom, sê Kaiser (1985:39) duidelik: 'Diese Gerechtigkeit hat sich im unbestechlichen Rechtsspruch und in einer Rechtspraxis und Gesetzgebung zu bewähren, die Freiheit und Lebensmöglichkeit der schwächsten Glieder der Gemeinschaft respektiert und sichert. In ihrer Unabdingbarkeit ist diese Forderung für sie alle göttlichen Ursprungs. Ihre Verletzung führt daher zu Heimsuchung und Untergang der Gesellschaft.'

Die profete het dus daarop aangedring dat mag en besit nie misbruik mag word nie en dat geregtigheid in die gees van broederlikheid uitgeoefen sal word. Hierdie vermanings het egter nooit in 'n sosiaal-politieke program omgeslaan nie. Die rede daarvoor was dat 'geregtigheid', alhoewel dit as die 'hoogste lewenswaarde' gesien was, nooit as 'n 'absolute sedelike norm' (Von Rad 1969:382) gefunksioneer het nie. Gedrag is in oud-Israel nie aan 'n ideale etiese norm gemeet nie, maar aan die bepaalde gemeenskapsverhouding self (vgl Von Rad 1969:383). Geregtigheid kon dus nie vasgevang word in byvoorbeeld die konsep van iustitia distributiva nie. Geregtigheid is nooit verselfstandig of verhef tot iets verhewe bo God nie. Die mens leef nie primêr voor die aansprake van 'n geregtigheidsidee nie, maar voor die aangesig van God. Dit is juis voor die aangesig van God waar ware geregtigheid ervaar word, want net God is (ge)reg(tigheid). Vanuit hierdie perspektief moet geregtigheid as 'n forensiese begrip verstaan word. (Von Rad 1969:382, 385, 389 het in sy verwerping van die forensiese gedagte, die begrip 'forensies' te eng verstaan as die 'staan voor 'n etiese norm'.)

Geregtigheid word in sy absoluutheid nie menslik gerealiseer nie, maar in en deur God se handelinge ervaar. God is geregtigheid omdat Hy regverdig oordeel (Ps 7:10, 12). God is die groot 'regshulp'. Hierdie regshulp het ook 'n strawwende en vernietigende kant. In die deursetting van sy reg help God nie net nie, maar Hy vernietig ook die onregverdige (vgl Kraus 1979: 51-52). Daarom mag daar van geregtigheid nie net 'n sosiaal-etiese kategorie gemaak word nie. God se geregtigheid, die absolute geregtigheid, is deel van God se reddende en strawwende handelinge. Juis daarom moet die menslike geregtigheid, die relatiewe geregtigheid, so ernstig opgeneem word aangesien dit nie in die sfeer van die heilswerk van God nie, maar in die sfeer van die gerig van God staan. Reuter (1990:174) stem hiermee saam en stel dit soos volg: 'Je konsequenter die Gerechtigkeit als Gottes eigenes Sein und Tun erkannt wird, desto mehr löst sich jene alteuropäische Tradition auf, welche Gerechtigkeit als Ausdruck der ganzen Tugend gefaßt bzw. als denjenigen Aspekt 
der vollkommenen Tugend analysiert hatte, der sich in Handlungen anderen gegenüber manifestiert.'

\section{DIE STAATSVORM KOMPLEMENTEREND AAN DIE EISE VAN DIE SKRIF}

Hier word van die aanname uitgegaan dat indien 'n mens die Bybelse uitsprake oor die owerheid, sy taak en sy funksionering van nader beskou, daar kwalik tot 'n ander gevolgtrekking gekom kan word as dat 'n demokratiese regstaatlikheid (vgl Honecker 1978:112-127) die beste staatsvorm vir die implementering van die Bybelse beginsels is. Die term 'demokraties' impliseer dat die mag aan 'n regering/party/ koning verleen word om in die beste belang van al die inwoners van 'n land te regeer. Hierdie party/koning is nie alwetend en alwys nie. Ruimte word gebied vir vermaning, kritiek en selfs verwerping van die regeerinstansie. Dit is juis op grond van hierdie punt dat Barth 'n noue affiniteit tussen die Christendom en die demokrasie gesien het (vgl Graf 1990b:736). Barth se standpunt was dat slegs die demokrasie ruimte skep vir die Bybelse gedagte van die begrensdheid van die mens, sy instellings, sy mag en sy prestasies. Die demokrasie help in die bewaring van die mens en die volk teen die totalitarisme. Die misbruik van mag word in 'n demokrasie tot 'n groot mate uitgeskakel deurdat daar 'n voortdurende kontrole oor die mag van die staat uitgeoefen word (vgl Hartmann 1981:219-233).

Regstaatlikheid hou in dat die regeerder(s) regeer volgens die norme van reg, geregtigheid en billikheid. Die regeerder(s) is egter nie die hoogste gesag nie, maar die reg; dié reg wat God liefhet. Jüngel (1985:709) het op sy beurt die affiniteit tussen regstaatlikheid en die Christelike geloof uitgewys. Volgens hom het 'n staat wat die gelykheid van al sy burgers voor die reg respekteer en waarborg, benadeelde minderhede beskerm, al sy organe en instellings aan die wet ondergeskik stel en altyd bereid is om sy eie en sy amptenare se foute te erken en reg te stel, 'n affiniteit tot die Christelike geloof. Binne hierdie staatsvorm is daar gevolglik ruimte vir vreedsame protes in die vorm van protesoptogte onderworpe aan sekere voorwaardes.

\section{DIE TEOLOGIESE ARGUMENTE TEN GUNSTE VAN DEMOKRATIE- SE REGSTAATLIKHEID}

5.1 Demokrasie en politieke kompromis

Die sterkste teologiese argument ten gunste van 'n demokrasie is dat die moraal waarop 'n demokrasie gebou word tot 'n groot mate met die etiek van die Nuwe Testament ooreenstem. Die morele fundus van 'n demokrasie lui soos volg: Ons moet en wil met mekaar en vir mekaar lewe (vgl Trillhaas 1970:466). Dit stem 
grootliks ooreen met Paulus wat gesê het: Julle moet nie net aan julle eie belange dink nie maar ook aan dié van ander (Flp 2:4). In 'n wêreld waar die selfsug, egoïsme en eie-belange die gang van die lewe grootliks bepaal, moet daar 'n ooreenkoms of 'n 'sosiale kontrak' tussen mense en groepe tot stand kom, indien hulle mekaar nie wedersyds wil vernietig nie. In hierdie ooreenkoms moet daar aan die ander se belange ook gedink word, net soos daar aan die eie-belange gedink sal word. Indien mense in vrede wil lewe, moet hulle kompromië aangaan waarin die meeste mense en groepe se belange geakkommodeer word.

Die realistiese van die demokrasie lê daarom in sy hanteringsmeganisme van botsende belange, naamlik die kompromis. (Hier word eerder volstaan met die term 'kompromis' bo die moeilik haalbare gedagte van 'konsensus' wat deur o a Fowler [1991:43-46] gebruik word.) Hierdie realistiese hanteringsmeganisme verstewig die morele basis van die demokratiese regeersisteem. Hierdie morele basis, en selfs in 'n sekere sin, geloofsbasis van die demokrasie gaan van die standpunt uit dat ons lot en toekoms met die lot en toekoms van ander onlosmaaklik saamhang. Die kompromis lè dus aan die basis van morele beslissings wat mér in ag neem as net die eie onmiddellike behoeftes, naamlik die toekoms en die vrede. Weer eens is hierdie kompromisbereidheid in lyn met wat Jesus geleer het: As iemand ' $n$ regsaak teen jou begin, kom betyds tot 'n skikking solank jy nog saam met hom op pad hof toe is... (Matt 5:25). Die moraal van die demokrasie (en van die Evangelie) lyk dus op die oog af onrealisties en wêreldvreemd, maar is in der waarheid juis realisties en werklikheidsgetrou. Dit is die beste moontlikheid om in vrede en rus te lewe, en om selfvernietiging te vermy. Die staat wat hierdie kompromië reël en uitvoer, moet daarom gerespekteer word en daar moet met hom saamgewerk word. Die staat mag daarom nie as die draak voorgehou word wat ten alle koste beveg moet word nie.

\section{S.2 Demokrasie en politieke toleransie}

Vir 'n demokrasie is die voortdurende bevordering van die toleransie-idee nie net nog 'n morele uitdaging nie, maar 'n wesenlike deel van die struktuur van die demokratiese besluitnemingsprosesse (Rendtorff 1981:92). Toleransie beteken dat politieke beslissings nie vir openbare kritiek geslote bly nie, maar kritiek juis toelaat. Verder beteken dit dat die regering toelaat dat groepe hulle inhoudelike afkeur teenoor 'n besluit kan uitspreek en demonstreer, met die verstandhouding dat hulle agting en wetlike respek vir hierdie besluit sal openbaar. Toleransie beteken verder dat opposisiegroepe dieselfde toleransiewilligheid sal openbaar en nie die demokrasie sal misbruik vir die afdwing van eie selfsugtige belange nie (vgl Rendtorff 1981: 93-95). 
Binne 'n religieus-pluralistiese, multikulturele samelewing is daar egter geen waarborg dat die toleransie-prinsiep effektief sal funksioneer nie. Graf (1990a:13) is reg as hy sê:

Eine Multikultur der Toleranz kann nur funktionieren, wenn alle in ihr Lebenden bereit sind, Unterscheidungsleistungen zu erbringen Unterscheidungen zwischen dem, was für alle gelten soll, und jenem, das nur für sich selbst gelten läßt. Wer solche Unterscheidungen nicht zu erbringen bereit ist, der verweigert einen Lernprozeß, der Toleranz alle in möglich werden läßt.

Indien die verskillende groeperinge dus nie daartoe in staat is om tussen eie en algemene belange te onderskei nie en algemene belange te erken nie, het die demokrasie in ' $n$ pluralistiese samelewing geen kans nie. Wat egter ook deeglik besef moet word, is die feit dat die Protestantisme oor geen tradisie van 'n prinsipiële pluralisme-ope kultuurteorie beskik nie en dat die prinsiep van toleransie waarskynlik iets spesifieks Westers is (vgl Graf 1990a:10-13 vir volledigheid). Dit impliseer dat, ten spyte van die edele morele (en selfs Christelike) appèlle vir toleransie, daar geen waarborg bestaan dat hierdie 'waarde' algemene instemming sal geniet nie.

Toleransie is, merkwaardig genoeg, nogtans 'n belangrike teologiese begrip. Ook hierdie aspek van die demokrasie kan teologies begrond word. Ebeling (1983b:101-130) het in ' $n$ belangwekkende artikel daarop gewys dat Luther belangrike uitsprake oor die tolerantia Dei gemaak het. Dit het hy gedoen in die derde reeks tesisse oor Romeine 3:28 in 1536 (WA 39,1,82-83). Vanuit Ebeling se artikel is die volgende afleidings wat hy uit Luther se nadenke gemaak het, vir ons van belang: Eerstens moet ons mekaar wys op die toleransie van God met die sondaar om weer eens te besef dat ons met mekaar as sondaars geduldig moet omgaan. Dit geld vir die regering, sy ondersteuner's en sy opposisie. Tweedens wys Ebeling daarop dat die toleransie-idee in ons tye so geïnterpreteer en uitgelê word dat ou probleme weer in 'n nuwe gewaad na vore tree. Onder die invloed van die Aufklärung noem hy dat die volgende gebeur het:

Die Struktur des alten Toleranzbegriffs: daß ein Übel...zur Verhinderung eines noch größeren Übels (der Bedrohung der pax publica) zu dulden sei, wurde durch die Aufklärung umgestülpt: Toleranz ist geboten, um dem edelsten Gut, der Freiheit des Menschen, Raum zu geben gegenüber dem Grundübel, der intoleranten Verquickung von Wahrheitsanspruch und Zwangsgewalt. Der Ort des Bösen im Toleranzphänomen hat somit gewechselt: Einst war das Böse dasjenige, was notgedrungen zu tolerieren ist, nun ist es dasjenige, was durch To- 
leranz beseitigt werden soll. Damit verändert sich auch Zweck und Ziel. Einst fügte man sich in ein unvermeidliches Übel...Von einer Vernichtung des Bösen konnte auf diesem Wege gerade nicht die Rede sein. Nun dagegen entsteht die Hoffnung auf einen unbegrenzten Sieg des Guten über das Böse.

(Ebeling 1983b:123)

Die konsekwensie van hierdie proses is die verskraiing van die sondebegrip tot moraal en die afplatting van die twee-ryke-leer tot 'n een-ryk-leer. Wanneer die realiteit van die sonde nie meer ernstig geneem word nie en mense dink hulle kan en moet die hemel op die aarde bring, verval mense in selfregverdigende intoleransie, waaruit nuwe brutaliteite gebore word (vgl Ebeling 1983b:124-130). Hierdie brutaliteite kom veral voor in die gestalte van die indeling van die mensdom in goeies en slegtes, die skuldiges en onskuldiges, die wat verantwoordelik is vir die bose en diegene wat daaronder moet ly. Die boosdoeners moet gestraf en beveg word en die lydende regverdiges moet beloon word - ' $n$ proses wat begin met die skuldbelydenisse van die booswigte (vir 'n vollediger agtergrondskets vgl Van Wyk 1990:5). Wanneer toleransie verstaan word soos Ebeling dit geskets het, sal die demokrasie geen kans gegun word nie, aangesien hierdie opvatting van toleransie net bydra tot ' $\mathrm{n}$ nuwe totalitêre heersersmentaliteit en vergeldingsisteem. Toleransie moet die element van verdraagsaamheid teenoor die staat, andersdenkendes, ander partye en ander groepe hê, indien dit as 'n grondwaarde in die demokrasie wil funksioneer.

\subsection{Demokrasie: die moontlikheid vir vrede}

Die etiese krag van die demokrasie lê in die kompromis- en toleransiebeginsels. Saam met die kompromisbereidheid bied die toleransiegewilligheid ' $n$ morele basis waarop konflikte binne perke gehou kan word en verhinder dat die een vir die ander ' $\mathrm{n}$ wolf sal word. Mens kan nie anders nie as om met Hobbes te voorspel wat gaan gebeur, as elkeen net op sy eie regte aanspraak maak. Hy het gesê (Hobbes 1839:166-170): 'Sou elkeen...op sy reg in alles staan, so sou die noodwendige gevolg...oorlog wees. [Dit sou 'n] oorlog van almal teen almal wees waardeur die mens vir sy medemens ' $n$ wolf sal word' (my vertaling).

\subsection{Protesoptogte as 'n bousteen in die demokrasie}

Dit lyk of (bloot teoreties gesien) daar binne 'n demokratiese regstaat ruimte moet wees vir openbare protes en wel in die vorm van protesoptogte. Protesoptogte bied aan burgers die geleentheid om voor die algemene publiek hulle ongelukkigheid teenoor die owerhede te demonstreer. Die toleransie van die owerhede om dit te 


\section{Protesoplogte}

duld bied aan hierdie twee partye nou die geleentheid om tot ' $n$ verstandige kompromis te kom en so die staatsgesag, vrede en publieke veiligheid te verseker.

Wettige en gewettigde protesoptogte val buite die kader van burgerlike ongehoorsaamheid. Dit is 'n legitieme en wettige wyse van protes en verset. (Vir die ingewikkelde verhouding tussen burgerlike ongehoorsaamheid en 'n demokratiese regstaat, vgl Habermas 1985:79-99.) Die veronderstelling sal altyd wees dat dit geweldloos en vreedsaam sal verloop en afloop. 'n Wettige protesoptog val dus in dieselfde kategorie as 'n smeekbede, petisie en ' $n$ wettige staking. In die lig hiervan is dit duidelik dat wettige protesoptogte byvoorbeeld nie met terreur of revolusie gelykgestel mag word nie. Dit lê ook nie op dieselfde vlak as bestuurlike ongehoorsaamheid, waar wetlike besluite nie uitgevoer word nie. Wettige protesoptogte veronderstel 'n demokratiese bestel, vryheid en verantwoordelikheid.

Onwettige protesoptogte kan as een faset van burgerlike ongehoorsaamheid gereken word (vgl Douma 1984:176-181). Douma (1984:177) verstaan, op voetspoor van Schuyt, onder burgerlike ongehoorsaamheid 'dat demonstratieve optreden dat bewust de wet schend om op dwingende - zij het geweldloos bedoelde - wijze verandering in een wet of maatregel van de overheid tot stand te brengen'. Al is 'n onwettige protesoptog demonstratief en al is die bedoeling dat dit vreedsaam sal verloop, kan dit nie noodwendig as 'n spelreël van die demokrasie gereken word nie. (Die vraag na burgerlike ongehoorsaamheid [vgl du Toit 1987], die reg van gewelddadige verset en opstand teen ' $n$ regering, sal dus nie in hierdie artikel aandag kry nie, aangesien dit buite die veronderstellings van hierdie tema lê.)

Daar moet deeglik besef word, en dit moet by herhaling gesê word, dat wetlike protes nie hemel op aarde gaan bring nie. Dit kan in sekere gevalle die hel op die aarde bring. Wanneer besluite nie meer in die parlement nie, maar op straat deur minderhede geneem en afgedwing word, kan dit selfs tot 'n burgeroorlog aanleiding gee. Dit sal gebeur wanneer die demokrasie in 'n oglokrasie verander word; wanneer die massas of die skares die land wil regeer (vgl Barkhuizen 1990:3). Wettige protesoptogte hou die maklike verleiding daartoe in.

Ten spyte daarvan dat ' $n$ mens begrip moet openbaar vir die reg en ook die noodsaaklikhid van protes (die mens moet God meer gehoorsaam wees as mense Hand 5:29), moet Romeine 13 ook weer hier as 'n meulsteen ingebring word. Protesoptogte mag nie misbruik word vir die ondermyning van die eis van Romeine 13 nie. Dit mag ook nie ontaard tot die aanblaas van burgerlike ongehoorsaamheid met die bedoeling om die land onregeerbaar te maak, indien 'n groep nie hulle sin kry nie. Douma het reg as hy beweer dat daar nie by 'n Christen die houding kan wees dat 'n mens slegs die owerheid gehoorsaam wanneer hy regeer volgens jou voorstellings van reg en geregtigheid nie. Hy sê: 
Ik verwerp deze halve of hele onwaarheden, omdat zij van onze gehoorsaamheid, in lijnrechte strijd met Romeinen 13, een actualistische aangeleendheid maken. Je bent gehoorzaam als de overheid goed doet, je mag onder haar uit als ze verkeerd doet. Gehoorzaamheid is niet wezenlijk voor de christen, maar functionel, en de beslissing mag telkens weer genomen worden. De overheid moet in dienst van God staan, dan gehoorzaam ik, anders niet. Romeinen 13 zegt echter - ik herhaal het - dat de overheid in dienst van God staat en dat ik haar dárom moet gehoorzamen. We lezen niet dat de overheid in dienst van God moet staan en dat ik haar dán moet gehoorzaam.

(Douma 1984:189)

Die grondbeginsel in die Christen moet dus steeds wees dat hy in moeilike situasies eerder sal wil ly as om te dreig. Die geleentheid tot openbare protes moet daarom nie hierdie beginsel in wankeling bring nie.

\subsection{Menswees en die reg}

'n Demokrasie behoort regstaatlikheid te veronderstel. Die doelwit en ideaal van 'n demokrasie is die implementering van die regspolitiek (Baruzzi 1990:20). Regstaatlikheid impliseer dat die staat grondwetstaat is. Die grondwet is die hoogste en omvattende raamwerk vir die wetgewing. Die staat se doen en late is daarom onderhewig aan die reg. Nie meer die staat, maar die reg is nou die nuwe monarg. Regering is die regering van die reg en heerskappy is die heerskappy van die reg (Baruzzi 1990:22).

Die hedendaagse heerskappy van die reg is goed te verstaan teen die agtergrond van die moderne antropologie. Die grondvraag van die moderne filosofie is, 'Wat is die mens?' Die antwoord op hierdie vraag word gegee teen die agtergrond van die kennisteorie. Baruzzi (1990:24) het die volgende motto saamgestel: '...in mente concipio [Galilei] bzw. ubi ergo generatio nulla...ibi nulla philosophia intelligitur [Hobbes]', en verstaan dit as volg: Die mens verstaan net, wat hy in homself konsipieer, hy kan net begryp wat hy self maak en self is. Kant $(1983: 23,26)$ het gesê 'daß die Vernunft nur das einsieht, was sie selbst nach ihrem Entwurfe hervorbringt', en dat 'wir nämlich von den Dingen nur das a priori erkennen, was wir selbst in sie legen'. Hieruit moet afgelei word dat die antropologie omskep is in 'n regsproses. Kant (1983:677) vra 'wat kan ek weet?' Hy vra nie meer wat is kennis nie, maar wat is vir my kennis. Hierdie vraag is nie quid facti nie, maar quid juris. Van belang is nie meer quaestio facti nie, maar quaestio juris. Met watter reg besit en gebruik ek woorde soos 'God' en 'vryheid'? In hoeverre kan ek met sulke begrippe die wêreld 
begryp? In dieselfde tydperk toe die mens verlig (aufgeklär) geword het oor sy kennis het hy ook begin aanspraak maak op sy regte. Oral het die regsvraag in die sentrum getree. Die mens het bewus geraak van die feit dat hy 'n reg het op reg. Die volgende aanhaling van Baruzzi (1990:27) gee 'n goeie aanduiding van wat in Europa gebeur het en van wat besig is om in Suid-Afrika te gebeur:

Zur Frage, was der Mensch als Mensch ist, gehört wesentlich, daß der Mensch als Mensch sein Recht, das Menschenrecht in allen Bereichen fordert. Ja, ich meine, daß im Recht am eindringlichsten jene neuzeitliche Haltung des Menschen sich zeigt, die auch Philosophie und Wissenschaften wesentlich bestimmt. Der Mensch will als Mensch in der Welt gegenüber allem und vor allem gegenüber sich selbst sich darstellen und behaupten. Das Recht bezeugt in eigenartiger und hervorragender Weise, was es heißt, daß der Mensch in der Neuzeit angefangen hat, voll und ganz Mensch zu werden. Das Recht ist jene Perspektive, unter welcher der Mensch sich und die Dinge, und das heiBt die Welt, sieht. Alles unterliegt der Rechtspespektive, und man könnte sogleich vermuten, da $\mathrm{B}$ sie dem Menschen angemessene sei.

\subsection{Protes en Menseregte}

Menseregte geld in die meeste state met 'n grondwet wat voorsiening maak vir demokratiese regstaatlikheid as 'n onmisbare element in die landsbestuur. 'n Mens is deeglik bewus van a! die gevare en leemtes wat so 'n handves kan inhou (vgl bv Du Toit 1988:20-28), maar dit mag nie verhinder dat daar na die positiewe aspekte verwys word nie.

Schwartländer (1977:205-238) noem die opkoms van die menseregte die 'grundlegendes Ereignis' van ons epog. Menseregte impliseer die 'Verbindlichkeit' en die 'Pflicht' tot 'n werksame humaniteit in die moderne wêreld. Menseregte is gerig teen elke vorm van absolutisme en totalitarisme, maak nie saak of dit in die gestalte van 'n absolute monargie of ' $n$ absolute demokrasie of 'n absolute parlementarisme is nie. Menseregte beskerm teen 'n blote meerderheidsdemokrasie en 'n volksdemokrasie sonder 'n opposisie. Die stryd van menseregte is gemik teen alle sisteme waarin mag nie afgestem is op die selfbeskikkingsreg van die burgers nie. Menseregte beskerm mense teen die willekeur van die staat. Die beskerming teen willekeurige inhegtenisname word selfs die 'Ur-Grundrecht' genoem. Om die willekeur van die staat aan bande te lêt is daar deur die loop van die agtiende eeu aangedring op stemreg, reg op vrye meningsuiting, samekomsvryheid, die reg op staatsburgerskap, die aanspraak op gelykheid voor die wet, die reg tot toegang tot openbare ampte en amptenare en die verbod op diskriminasie. Laasgenoemde het ontwikkel 
tot die aandrang op beskerming van minderhede en tot die eis op politieke selfbeskikking deur volke (Schwartländer 1977:214).

Menseregte dien die belange van elke inwoner. Voordat mense self protesteer, protesteer die handves alreeds teen die owerheid se magsmisbruik in terme van die reg van die burgers op vryheid en selfbeskikking. 'n Handves van menseregte ondervang dus in 'n mate die openbare protes en bewaar die samelewing van onnodige konflik en geweld.

\section{DIE STAAT AS 'N NOODORDENING AS GEVOLG VAN DIE SONDE}

Die Nederlandse Geloofsbelydenis (Art 36) leer die volgende in verband met die staat: 'Ons glo dat ons goeie God vanweë die verdorwenheid van die menslike geslag, konings, vorste en owerhede aangestel het. Dit is immers sy wil dat die wêreld deur middel van die wette en regerings geregeer moet word, sodat die losbandigheid van die mense in bedwang gehou kan word en alles onder die mense ordelik kan verloop.'

Hierdie verstaan van die staat is ingebed in 'n lang teologiese tradisie. Hier word kortliks net na Augustinus verwys. (Aangesien ek daartoe neig om op sekere punte 'n meer Lutherse standpunt te volg, is dit nodig om daarop te wys dat dit juis op hierdie punt is waar die Lutherse en Gereformeerde tradisies dit met mekaar eens is. Ek het elders (Van Wyk:321-329) 'n breedvoerige uiteensetting gegee van Luther se staatsopvatting wat ooreenstem met dit wat nou aangebied word.) Die laat hoofwerk van Augustinus De civitate Dei (413-426) wat as sy 'teologie van die politiek' (Ruokanen 1988:22) bekend staan kan as die beginpunt van hierdie denktradisie geld. Ruokanen (1988:22-39) wys in sy uiters insiggewende artikel daarop dat Augustinus se hoofwerk nie vanuit die Skolastiek verstaan moet word nie. Hy het die staat nie as 'n lewensordening gesien wat geïdentifiseer moet word met 'n oorspronklike skeppingsordening van God nie. Hy het daarom ook nie die volgende skolastiese idees, wat na die antieke teruggevoer kan word, gesteun nie: die magsverhoudinge van die staat wat volgens die patriargale pater familias-prinsiep opgebou moet word naamlik dat die geringe die belangrike onderdanig moet wees, soos die kind sy vader en die liggaam die gees. Verder het hy die gedagte dat die staat die vooronderstelling van die realisering van die goeie is, verwerp. Die staat het nie volgens hom die opgawe van moraal-opvoeder nie. So breek Augustinus met die gedagte van Plato en die Stoïsyne dat die staat en sy magsuitvoering op die prinsiep van geregtigheid berus.

Augustinus gaan van die veronderstelling van die twee ryke uit naamlik die civitas Dei en die civitas terrena. In die civitas terrena word die liefde op die geskape dinge gerig en so word iets buiten God as die hoogste goed liefgehê. Hieruit volg 
die versteuring van die oorspronklike liefdesorde (ordo amoris). Die substansie van hierdie ryk is die selfliefde (amor sui), die begeerlikheid (cupiditas) en die hoogmoed (superbia). Die belangrikste verskyningsvorm van hierdie sondes is die op ander gerigte magsgier (libido dominandi). Deurdat die mens ander wil onderwerp, dien hy sy eie begeerlikheid na lof en eer (cupiditas laudis et gloriae). Augustinus beklemtoon dit egter dat die skeppingsorde nie 'n oorspronklike onderwerpingssisteem gehad het nie, maar slegs 'n tussenmenslike aequilitas sub Deo. Hy (DCD $X 1 X, 12)$ sê: 'So aap die hoogmoed op verkeerde wyse God na. Hy haat die gelykheid met die medemens onder God en wil eerder in die plek van God sy heerskappy die mense oplê.' Op grond van die skepping is die mens wel 'n animal sociale, maar nie ' $n$ animal politicum nie. Die maatskaplike onderwerpingsisteme is dus nie ' $n$ orde van die goeie skepping nie, maar die gevolg van die sonde. Magsuitoefening berus op die sondeval en die daaruit voortvloeiende heersug, libido dominandi. Augustinus rig hom teen Cicero se staatsopvatting dat die gemeenskapslewe op 'n definisie van geregtigheid berus.

Saam met die Romeinse historikus Gaius Sallust Crispus (86-35 v C) wil hy bewys dat Rome se toestand as staat altyd die slegste en skandaligste (pessima ac flagitiosissima) was. Omdat Romelus vir Remus doodgemaak het, was die Romeinse staat op heersug, geweld en onreg gegrond. Cicero se idee dat hierdie staat op geregtigheid gegrond was, was dus idealisties. Ware geregtigheid is volgens Augustinus slegs 'n objek van die geloof en die hoop en is so nooit'n voor die handliggende realiteit nie. Daarom kon hy sê (DCD X1X,27): 'Ook ons regskapenheid is, alhoewel dit waar is weens die ware goeie doel, waarop dit betrekking het, nogtans in hierdie lewe so gering, dat dit eerder in die vergewing van die sondes as in die volkomenheid van die deugde bestaan.' Die eie waarde van die Christelike iustitia le daarom in die sfeer van die soteriologiese geloof en die eskatologiese hoop. Net in die ryk van God is die gemeenskapslewe op die geregtigheid begrond. Hierdie is egter 'n eskatologiese saak. Die staat is op eie-nuttige liefde (cupiditas) begrond. Die staat is daarom 'n suiwer sekuler-menslike grootheid en geen skepping van God nie. Gemeenskaplike egoïstiese doelwitte, wat heel dikwels irrasioneel is, bepaal die magsuitoefening. ' $n$ Gemeenskaplike geregtigheidsopvatting kan nie 'n volk verenig nie. Ten spyte hiervan meen Augustinus nogtans dat die magsuitoefening wat 'n konsekwensie van die sonde is, tog deel uitmaak van die voorsienigheid van God. God gebruik hierdie euwel as 'n noodordening om die verwoestingskragte in toom te hou. Die onderwerping onder ' $n$ regeerder verminder die vernietiging van die corlog van almal teen almal. In die samelewing moet die Christene die magsuitoefening as sondegevolg en as straf sien en met alle ander mense saamwerk tot behoud van die sterflike lewe (ad sustenandam mortali vitae). 
Ek meen dat dit noodsaaklik is dat bogenoemde perspektiewe weer die nodige aandag sal kry. Mense en partye sal baie teleurstellings en frustrasies gespaar word en die samelewing en die staat sal onnodige emosie-belaaide protesoptogte gespaar word wanneer daar weer besef word dat absolute geregtigheid nie bestaan en nie handelend waargemaak kan word nie. Ook nie voortdurende protes en selfs revolusie sal hierdie feitelikheid kan verander nie. Voortdurende protes ten gunste van meer geregtigheid en selfs die wetlike gestaltegewing van sekere geregtigheidsvoorstellings sal die iustitia civilis nie in die sfeer van die iustitia Dei bring nie. Ook die profetiese teologie (vgl die Kairos-dokument 1986; The Road to Damascus 1989) sal nie 'n eenduidige geskiedenisinterpretasie kan afdwing nie (vgl Honecker 1982a:6567); ' $n$ interpretasie dus van 'n samelewing waarin almal dieselfde (omnibus eadem) en tegelyk elkeen sy eie (suum cuique) ontvang; 'n samelewing waarin daar dus 'n perfekte balans is tussen die iustitia commutativa en die iustitia distributiva. Alle geregtigheidsfanatici moet aan die volgende woorde van Bayer (1984:211-212) herinner word:

Auch ein aus dem Evangelium erwachsenes Recht...gehört als allgemein gewordene Humanität nicht identifizierbar zur neuen Welt der iustitia dei, sondern zur vergehenden Welt, die nicht ohne Sünde ist, in der auch das Handeln des Christen der Zweideutigkeit nicht entnommen ist und das Gericht nach den Werken noch vor sich hat. Auch ein aus dem Evangelium erwachsenes Recht ist ein Mittel von Gottes erhaltendem Schöpferhandeln, ein Mittel seiner Langmut und Geduld, in der er die Welt bewahrt und auf seine Zukunft hin erhält.

\section{PROTESOPTOGTE AS DIE BEVESTIGING VAN DIE WERKLIKHEIDS- VISIE EN STAATSOPVATTING VAN DIE BYBEL}

Protesoptogte is 'n goeie weerspieëling en bevestiging van die werklikheidsvisie van die Skrif. Rondom protesoptogte kry 'n mens sigbaar 'n voorstelling van die twee aspekte van die staat wat ons tot hiertoe wou uitwys naamlik die onvolmaaktheid van 'n regering en die noodsaaklike ruimte wat vir protes geskep moet word en aan die ander kant die noodsaaklikheid van 'n sterk regering om geweld en moord in bedwang te hou. Afgesien van die positiewe aspekte is daar daarom ook 'n hele aantal negatiewe aspekte aan protesoptogte verbonde. Die twee aspekte word nou puntsgewys genoem: 
7.1 Die positiewe aspekte

- Groepe en individue kry die reg en vryheid van spraak, meningsuiting en meningsvorming.

- Die gevoelens en menings van mense wat in die verlede nie gehoor is nie en tans nie meer gehoor word nie, word nou gehoor.

- Vreedsame betogings kan aanleiding gee tot groter begrip van probleme en frustrasies.

- Opgekropte gevoelens en frustrasies kan ontlaai word.

- Diegene sonder politieke regte en sonder politieke mag kan gehoor en gesien word. Die gevoel van totale regloosheid en magloosheid kan verflou.

- Geweld en terrorisme kan afneem indien mense weet hulle mening word gehoor, gesien en bekendgemaak.

- Vreedsame protes kan gewelddadige protes laat afneem.

- Reg en geregtigheid kan bevorder word.

- Vreedsame protes is een hoeksteen van 'n veelparty-demokrasie wat deur regstaatlikheid gerugsteun word. Die vryheid van spraak en die reg tot meningsverskil word so gerespekteer.

7.2 Die probleme, knelpunte en gevare

- Die veiligheid van die publiek kan nie gewaarborg word nie.

- Die veiligheid van eiendom kan nie gewaarborg word nie.

- Die moontlikheid van geweld is nie uitgesluit nie.

- Die publiek kan uitgetart word.

- Daar word inbraak gemaak op die reg en vryheid van beweging en ontspanning van die publiek.

- Die vervoerwese en sakebedrywighede word ontwrig.

- Kriminele elemente gebruik hierdie geleenthede vir hulle bedrywighede.

- Liedere wat gesing word, kan wraak-, geweld- en moordneigings aanblaas.

- Haat en wrokgevoelens kan by die teenstanders van die betogers opgewek word.

- Die konflikpotensiaal kan geweldig toeneem.

- Teenproteste kan tot grootskaalse geweld lei.

- Die misbruik van kinders kan voorkom. Dit is eties en opvoedkundig onaanvaarbaar.

- Die intimidasie van nie-betogers kan voorkom wat demokraties onverdedigbaar is.

- Die vreedsame betogings vir 'n bepaalde saak is dikwels slegs deel van 'n groter magspolitieke proses. 
- Hierdie betogings bring geweldige onkostes vir die staat mee. Polisie-optrede in so 'n situasie is geweldig duur. Die gebruik van helikopters en ander gesofistikeerde toerusting is ' $n$ groot finansiële uitleg.

- Die werkslas, stres en beproewing wat protesoptogte op die polisie laai, is onbillik en onregverdig teenoor hulle en hulle gesinne.

- Die protesoptogte neem so baie tyd van die polisiemag in beslag, dat daar byna nie meer tyd is vir hulle eintlike taak, naamlik misdaadbekamping nie.

- Die polisie is in diens van die gemeenskap en nie in diens van die regering nie. Protesoptogte is 'n aksie teen die regering. Om hierdie protes te beheer word die polisie hoofsaaklik gebruik. In hierdie opsig kan die polisie dan 'n instrument van die regering word om regeringsbeleid in stand te hou. Hierdeur kan die verhouding tussen die polisie en die gemeenskap ernstig bedreig word.

- Protesoptogte kan die hefboom word van selfsugtige, onverantwoordelike, oningeligte mense en groepe, wat deur middel van protesoptogte en stakings maatskappye, myne en ander instansies tot bankrotskap kan dwing en so lyding oor duisende ander mense kan bring.

- Die meeste van hierdie probleme kan teruggevoer word na die feit dat 'n mens by 'n protesoptog met 'n skare te make het wat minstens die volgende eienskappe openbaar:

** Homogeniteit: Dit bestaan in die geestelike eensgesindheid van die groepslede. As groep toon hulle dieselfde houdings en opvattings, frustrasies en vooroordele.

** Emosionaliteit: Die hoë graad van emosionele spanning en opwinding is noodsaaklik vir die bestendiging van die groep.

** Irrasionaliteit: Irrasionaliteit gee aanleiding tot impulsiewe groepsgedrag. Die hipnotiese gemeenskaplike emosie oorheers die denke en nugtere beredenering.

** Anonimiteit: In hierdie toestand vind 'n tydelike verlies van persoonlike identiteit en rasionaliteit plaas. Dit skep 'n gewaande toestand van vryheid om voorskrifte en beperkinge te verontagsaam waardeur aanspreeklikheid vir individuele gedrag nie aanvaar hoef te word nie.

** Universaliteit: Dit lê opgesluit in die gemeenskaplikheid van denke, opvattinge en doelwitte. Dit skep die oortuiging by die groep dat hulle die gevoel en houding van die meerderheid in die samelewing weerspiëel (vgl Van Heerden 1982:238-248 vir volledigheid).

- Die volgende psigologiese invloede gee aanleiding tot bogenoemde gedrag van skares wat van protesoptogte monsters in die gemeenskap kan maak: 
** Die nuwigheid en andersheid van groepsgedrag bied die geleentheid om 'n onbewuste drang om van roetine te ontsnap, te bevredig.

** Die groepsatmosfeer bied aan die individu die geleentheid om uiting te gee aan onderdrukte emosies.

* Die groot getal mense wat eenders dink en optree skep die gevoel van mag en die begeerte om dit te gebruik.

** Die mens se behoefte om gelei te word, word in hierdie situasie deur die leierselement uitgebuit, tot dikwels skadelike gevolge vir die individu.

- Protesoptogte kan so maklik die teenoorgestelde gevolge vir die protesteerders hê as wat hulle geantisipeer het. In plaas van simpatie kan hulle verwerping by die gemeenskap ontlok; in plaas van begrip kan hulle bespotting ontlok.

Konkluderend kan gemeld word dat wettige protesoptogte 'n noodsaaklike, wenslike en onontbeerlike element van 'n demokratiese regstaat blyk te wees. Dit kan egter maklik ontaard tot 'n uiters ambivalente en selfs onwenslike saak as gevolg van die sonde. Die staat behoort daarom ruimte te laat vir protesoptogte, maar moet hom ook die reg voorbehou om hierdie praktyk te staak indien dit tot nadeel van die gemeenskap misbruik word.

\section{DIE ROL VAN DIE KERK}

Die kerk het die verantwoordelikheid om teenoor die volk en die owerheid te getuig. Die basiese van hierdie getuienis kom daarop neer dat die volk (die hele volk en nasie) weer opnuut ingelig sal word oor die eis tot gehoorsaamheid, maar ook oor die reg op vreedsame protes en dat die regering vermaan sal word oor die regmatige eis tot reg, geregtigheid en veiligheid.

\subsection{Die kerk se getuienistaak: Prinsipiẽle vertrekpunte}

Barmen Teologiese Verklaring Tese 5 lees soos volg: 'Fürchtet Gott, ehret den König!' (1 Petr 2:17).

Die Schrift sagt uns, daß der Staat nach göttlicher Anordnung die Aufgabe hat, in der noch nicht erlösten Welt, in der auch die Kirche steht, nach dem $\mathrm{Ma} B$ menschlicher Einsicht und menschlichen Vermögens unter Androhung und Ausübung von Gewalt für Recht und Frieden zu sorgen. Die Kirche erkennt in Dank und Ehrfurcht gegen Gott die Wohltat dieser seiner Anordnung an. Sie erinnert an Gottes Reich, an Gottes Gebot und Gerechtigkeit und damit an die Verantwortung der Regierenden und Regierten. Sie vertraut und gehorcht der Kraft des Wortes, durch das Gott alle Dinge trägt. 
Wir verwerfen die falsche Lehre, als solle und könne der Staat über seinen besonderen Auftrag hinaus die einzige und totale Ordnung menschlichen Lebens werden und also auch die Bestimmung der Kirche erfüllen.

Wir verwerfen die falsche Lehre, als solle und könne sich die Kirche über ihren besonderen Auftrag hinaus staatliche Art, staatliche Aufgaben und staatliche Würde aneignen und damit selbst zu einem Organ des Staates werden.

Die kerk kan maklik verlei word om sak en pak by die magspolitieke spel betrokke te raak. Op aandrang van individue en groepe kan die kerk in die strik trap om konkrete beslissings te gee, kant te kies, handelingsdirektiewe aan te bied en oordelend en veroordelend mense en instansies van die Evangelie te vervreem. Dit kan sekerlik nie die weg van die kerk en die teologie wees om deel te word van die politieke magspel nie. Die kerk moet betrokke wees by die problematiek van die maatskappy, maar op 'n ander wyse as die regering, partye en vakbonde. Die kerk moet meer sê en iets anders sê as die strydende partye. Dit impliseer, om dit met Karl Barth (1985:509) te sê: 'Das Göttliche darf nicht politisiert und das Menschliche nicht theologisiert werden, auch nicht zugunsten der Demokratie und Sozialdemokratie.' Die vertrekpunt moet dus wees dat daar 'n onderskeiding en nie 'n totale skeiding tussen kerk en staat sal wees nie. Wanneer daar 'n totale skeiding van geloof en politick, kerk en staat na vore tree en godsdiens deur en deur 'n private aangeleentheid word, word die staat beroof van sy enigste werklike integrasiebasis, naamlik die Christelike godsdiens. Rohrmoser (1989:34) het onlangs daarop gewys dat die uiteindelike gevolg van so 'n radikale skeiding tussen godsdiens en staatswese die totale verval van alle singewende waardes, die oriënteringsloosheid van die burgers en die betekenisloosheid van die samelewing is.

Ons moet dus daarteen waak dat ons staat nie cok sal verval in 'n formele regstaat wat bloot instrument is van die selforganisasie van ' $n$ 'libertyns-hedonistiese' samelewing nie. So 'n staat kan geen sedelike staat meer wees nie. Daar moet dus op een of ander wyse 'n band tussen geloof en politick, kerk en staat wees. Die twee-ryke-leer kan en mag nie sonder die koningsheerskappy van Christus funksioneer nie. Tog moet daar ernstig gewaak word teen die klerikalisering van die politiek. Dit was juis Barth (vgl Graf 1990b:735-738), wat as Calvinis die gedagte van die koningsheerskappy so heftig bevorder het, wat ernstig teen die klerikalisering van die politiek gewaarsku het. Die koningsheerskappy van Christus kan volgens Barth nooit met kultureel-politiekc magsaansprake geïdentifisecr word nie. Dit verhinder die 'Christengemeente' nog nie om 'n leidinggewende polities-kulturele rol in die 'burgergemeente' te speel nie. 
Die volgende belangrike saak is dat die politieke relevansie van die kerk en teologie hom aan sy spreke oor God moet bewys. Die teologie mag nie met kwasi-politieke kategorië 'n kwasi-politieke teorie formuleer, waarvan die resultaat op die ou einde 'n kwasi-politieke praktyk is nie (Van Wyk 1987:336). Die kerk se spreke oor God word bepaal deur die onderwerp (Gegenstand) van die teologie. Hierdie onderwerp of eintlike saak moet met Luther soos volg geformuleer word: 'Die karakteristieke onderwerp van die teologie is die mens wat weens die sonde skuldig en verwerplik is en God, wat die sondige mens regverdig en red. Wat buite hierdie onderwerp om in die teologie nagevors en uitgewerk word, is dwaling en gif (WA 40/11, $328,17-20$ - my vertaling). Die sentrale uitdaging van die teologie moet mens dus soek in die spreke oor God in sy verhouding tot die mens en nie in die besinning oor alle moontlike sosiologiese omstandighede van die vroomheid nie.

Die kerk en die teologie praat oor die geloof en wel van die geloof wat instem in wat God reeds vir ons gedoen het. Die geloof is nie gerig op dit wat ons eers deur middel van ons handelinge tot stand kan bring nie, maar op dit wat al ons doen en late voorafgaan. So 'n teologie geld dan as 'n werklike teologiese teologie, aangesien dit op 'n gegewendheid gerig is wat nie handelend waargemaak kan word nie. Wanneer teologie so verstaan word is 'n politieke teologie nie toelaatbaar nie, wel egter 'n 'teologiese etiek van die politieke', wat 'n etiek is wat nie omslaan in geloofsleer nie en wat nie handelingsaanwysinge dogmatiseer nie. So 'n teologiese etiek sal dus gerig wees op begrensde doelwitte (vgl Honecker 1982b:377-384) en sal uitmond in die werklike kuns van die moontlike en so op die sogenaamde 'Realpolitik' (vgl Sauter 1984:136). Op hierdie wyse sal mense nie onder die waan gebring word dat protesoptogte 'n werkbare meganisme is vir die realisering van utopiese wense nie. Daar sal ruimte gelaat word vir die handelinge van God in die wêreld, en op Hom vertrou word met die bewaring van sy skepping en die voorsiening aan sy skepsels.

Die kerk en die teologie is nie vanuit hulle uitgangspunte gerig op sosiaal-politieke probleme en konflikte nie. Die spreke oor God is die taak van die kerk en die teologie. Aangesien hulle oor God praat in die lig van die werklikhede wat Hy reeds waargemaak het en wat nou die inhoud van die geloof en die hoop van die kerk is, is dit nie die taak van die kerk om handelend soortgelyke werklikhede utopisties te probeer realiseer nie. Die kerk kan hom rig op die relatiewe bevordering van 'n humane samelewing deur middel van sy aanpak van begrensde doelwitte wat realistiese uitdagings blyk te wees. Prakties sal dit beteken dat die kerk nie kan aandring op 'n onmiddellike skep van totaal regverdige verhoudinge (bv in 'n arbeidsituasie) nie. Die kerk kan byvoorbeeld net aandring op die verbetering van werkers se salarisse of hulle huisvesting binne die perke van die moontlikhede. Die kerk sal 
daarop moet wys dat sy appêl op geregtigheid nie politieke en ekonomiese argumente wil vervang nie. Die gewetes moet verskerp word sodat daar op 'n verantwoordelike wyse met die verstand relatiewe verbeterings aangebring kan word aan 'n bepaalde situasie. Die koninkryk van vrede, reg en geregtigheid kan dus nie in hierdie wêreld handelend gerealiseer word nie. Dit bly 'n eskatologiese saak waarop die geloof gerig is.

Waarvoor saam met Sauter (1985:437) en Lehmann (1987) hier gepleit word, is ' $n$ 'teologiese hermeneutiek van die politieke' in plaas van 'n politieke hermeneutiek van die teologie (vgl Moltmann 1976:293-315). Die teoloog bewaar op hierdie wyse die wêreldlikheid van die wêreld en so die koninklike rol van die menslike rede. Wêreldlikheid en redelikheid gaan juis daar verlore waar mense nie meer die wêreld in die hande van God wil laat nie of Hom daarmee wil vertrou nie en dus meen hulle moet 'n Goddelike wêreld skep - 'n wêreld van volkome geregtigheid.

'n Teologiese hermeneutiek van die politieke skep 'n gelatenheid teenoor dit wat nou eenmaal is. Dit beteken nie 'n onbetrokkenheid en onverantwoordelikheid teenoor die wêreld nie, maar slegs die bevryding van die dwang om alles nou te wil verander en nou die volmaakte te wil realiseer. Die vryheid word gebied om stap vir stap, volgens die insigte van die verstand, 'n beter, regverdiger wêreld te skep.

Die regverdigingsleer en die teologiese hermeneutiek van die politieke skep by die gelowige ' $n$ heel besondere houding teenoor die politieke woelinge en die mense wat daarby betrokke is. Die gelowige word daarvan bewaar dat hy homself nie ook skuldig maak aan dit waarvan die bevrydingsteoloë beskuldig kan word nie. By hulle word eensydige beslissings bindend afgedwing. So word daar deur 'n eensydige partyname fronte geskep wat die wêreld indeel in goeies en slegtes. So volg die politieke teologie die politieke spelreëls van die vriend-vyand denke en die politieke taktiek van polarisering. Die Evangelie verteenwoordig egter geen politieke party nie. Die kerk moet daarom krities teenoor alle partye bly. Die Christen as vrye mens word nie 'n meeloper van 'n bepaalde party, vakbond of groep nie. Hy het die vryheid om objektief te oordeel oor die waarheid en die eties gebiedende. Hy het dus die vryheid tot onpartydige liefde (vgl Ebeling 1983a:47-48). Die Christen en die kerkleiding behoort dus ' $n$ totaal ander houding in te neem as die bevrydingsteoloë. Daar mag nie eensydig kant gekies word vir sekere partye en belangegroepe nie. Die kerk moet hom daarom veral daarvan weerhou om sanksie te verleen aan sekere groepe se protesoptogte deur self amptelik daaraan deel te neem of openbare verklarings ten gunste van die protesteerders te maak.

Hierdie andersheid in optrede kan veral teruggevoer word na die verstaan van die 'gewete'. Die grondstruktuur van die gewetensfenomeen by die Bevrydingsteologie (die regse politieke teologie kan ook hier gereken word) word gekenmerk deur 
die (aan)drang om handelend sekere lewensverwagtings te verwesenlik. Die gewete word so verander tot die 'plig' teenoor die groep en sy ideale. Die gewete verword tot die 'stem' van die party of die volk. Gewete slaan so om in 'n sosialiserings- en motiveringsmeganisme. Die neiging ontwikkel dan om jouself as medewerker in hierdie proses as die regverdige te sien en diegene wat nie daaraan deel het nie, aan te kla as die skuldiges. Die gewete is so die impuls tot die meedoen aan vasgestelde lewensimperatiewe. Luther (vgl Ebeling 1983e:195-196; Lohse 1974) het egter die gewete totaal anders verstaan. Vir hom impliseer 'gewete' die totale syn van die mens voor God en wel as die syn voor die nou al reeds teenwoordige eindoordeel. Die gewete dwing die mens dus nie tot ywerige, selfversekerde en selfregverdigende optrede nie, maar tot versigtige keuses tot wat nou moontlik en haalbaar is. Die gewete dwing mense dus tot stilstand en nadenke oor hulle weg en mening. Dit laat mense besef dat hulle nie besig is om God se koninkryk te voltooi nie, maar om heel menslik die humaniteit te probeer bevorder. Pannenberg (1983:290) het dit uitgewys dat die funksie van die gewete in die Nuwe Testament 'n oordelende en nie 'n wetgewende of rigtingduidende funksie is nie. Luther (WA 8, 606, 30-35) wat dit ook al geweet het, het in sy geskrif De votis monasticis (1521) reeds die volgende uitspraak gemaak: 'Daarom is die Christelike of evangeliese vryheid die vryheid van die gewete, waardeur die gewete van die werke bevry word, nie sodat geen werke meer sal voorkom nie, maar dat daar nie daarop vertrou word nie. Die gewete is nie die vaardigheid om werke te doen nie, maar die vaardigheid om te oordeel oor die werke' (my vertaling). Die staat of die volk of die party kan nie die mens se gewete wees nie, want hierdie instellings het nie 'n gewete nie. Slegs individue het 'n gewete. Die gewete mag nie versosialiseer word nie (Pannenberg 1983:297), want dit sal aanleiding gee tot 'n nuwe vorm van morele dwang. Ook die kerk moet vir lidmate ruimte laat om self te oordeel oor politieke sake, soos Manensehijn (s a:138) dit dan ook stel:

Niet de kerk is de beslissende bemiddelende instantie tussen geloof en politiek, maar de gelovige zelf. In zijn geweten beslist hij, hó de relatie tussen geloof en politiek te leggen. Geen macht ter wereld, ook de keklijke macht niet, mag de gewetens binden. En geen gelovige mag aan zijn geweten absolute beslissingsbevoegdheid toekennen. Het gaat niet om zijn ethische onfeilbaarheid, maar om zijn morele integriteit. De erkenning daarvan moet hem genoeg zijn. 
82 Die kerk se verkondigingstaak teenoor die volk (en nasie)

- Die kerk moet sy lidmate, sy volk en die hele nasie oproep om die staat te gehoorsaam en om nie gewelddadig teen die owerheid in opstand te kom nie.

- Die kerk moet die onderdane daarop wys dat hulle 'n reg tot protes het. Hierdie protes kan en moet volgens die spelreëls van die demokrasie tot uiting kom.

- Die kerk moet die bevolking daarop wys dat hy realisties moet wees oor die vrugte van sy protes. In die onverloste wêreld kan die hemel nie gerealiseer word nie.

- Protesoptogte mag nie gesien word as 'n towerformule vir die afdwing van 'n ideale samelewing nie.

- Die burgery moet bedag gemaak word op die konsekwensies van protesoptogte soos byvoorbeeld die finansiële implikasies, die gevolge vir die polisie, die vrees wat in 'n bepaalde stad aangeblaas word en die moontlikheid van geweld.

- Die gelowiges moet met die Woord getroos word. Daar moet minstens na die volgende sake verwys word:

* Die koningskap van Christus.

* Die oordeel van God.

** Die eskatologiese visie op reg, geregtigheid, billikheid en vrede.

- Die kerk moet ook na een belangrike opvoedkundige dimensie verwys en ouers ernstig aanspreek oor die verwarrende persepsies van gesag wat hulle by kinders skep wanneer hulle die gesag van die owerheid verwerp, maar dan weer hulle eie gesag of die gesag van 'n beweging of organisasie, outoritêr op hulle afdwing.

- Die volk, partye of groeperinge kan nie van die kerk verwag om kant te kies in hulle stryd nie.

- Die kerk kan ook nie op alle politiek-maatskaplike sake kommentaar lewer nie. Sy kommentaar en spreke is gebind aan sy onderwerp - die sondige mens en die regverdigende God.

- Die kerk sal van sy ampsdraers en veral van sy predikante verwag om nie aan protesoptogte deel te neem nie, sodat die kerk nie met bepaalde drukgroepe geïdentifiseer kan word nie.

- Die kerk sal sy lidmata daarop moet wys dat die opgaan in die strate nie die opgaan na die Huis van die Here kan en mag vervang nie.

- Die kerk sal sy lidmate moet waarsku dat hulle daarteen moet waak dat hulle politiek nie hulle geloof word nie.

- Die kerk sal sy lidmate en veral sy predikante moet versoek om nie aan onwettige optogte deel te neem nie. 
8.3 Die kerk se verkondigingstaak teenoor die owerheid

- Die kerk sal die owerheid moet wys op die reg van die burgers tot verset. Die kerk moet dus aandring op gereelde verkiesings en op ruimte vir vreedsame protes.

- Die kerk sal die breë beginsels ten opsigte van reg, geregtigheid, billikheid, vrede en veiligheid gereeld onder die aandag van die regering moet bring.

- Die staat sal op sy hoë roeping gewys moet word. As dienskneg van God sal hy met die swaard moet sorg vir regmatige straf. Kwaaddoeners en booswigte, geweldenaars en moordenaars moet gestraf word om op hierdie wyse almal weer te herinner aan die oordeel van God.

- Die kerk moet die staat verseker van sy kritiese onpartydigheid.

- Die kerk sal die staat en die regeerders gereeld moet verseker van sy voorbidding.

- Die regeerders sal gereeld herinner moet word aan die oordeel van God oor diegene wat nie ag slaan op God se eise van reg en geregtigheid nie.

- Die staat sal daarop gewys moet word dat hy die vryheid en outonomie van die kerk moet eerbiedig.

- Die staat sal grense en perke moet stel aan mense en selfs kerke se vryheid, indien hulle optredes die vryheid van ander mense en kerke bedreig.

- Die staat moet versoek word om die nodige toleransie teenoor sy opponente te openbaar, om so die spelreëls van die demokrasie te eerbiedig.

- Van die staat sal verwag word om te alle tye die veiligheid van mense en hulle eiendom te beskerm.

- Van die staat word verwag om die praktyk van protesoptogte te staak indien hierdie praktyk as gevolg van die kollektiewe egoïsme van groepe, groter probleme skep as wat hulle oplos.

- Die regering moet versoek word dat toegesien word dat die demokrasie nie met 'n oglokrasie vervang word nie.

\section{Literatuurverwysings}

Augustinus, D 1954vv. De civitate Dei. Tournhout. Vanuit Corpus Christianorum, reeks Latina.

Barkhuizen, J H 1990. Demokrasie en die nuwe Suid-Afrika. Die Hervormer 1 Oktober, 3.

Barth, K 1985. Der Römerbrief. Zürich.

Baruzzi, A 1990. Freiheit, Recht und Gemeinwohl: Grundfragen einer Rechtsphilosophie. Darmstadt: Wissenschaftliche Buchgesellschaft. 
Bayer, O 1984. Macht, Recht, Gerechtigkeit. KuD 30, 200-212.

Douma, J 1984. Politieke Verantwoordelijkheid. Kampen: Uitgeverij van den Berg. (Ethische bezinning: $\mathrm{nr} 13$.

Du Toit, D (samesteller) 1987. Staatsgesag en burgerlike ongehoorsaamheid. Kaapstad: Lux Verbi.

..- 1988. Die mens en sy regte: Geloof en praktyk in Suid-Afrika. Kaapstad: Zebra publikasies. (RGN Publikasiereeksnommer 88.)

Ebeling, G 1983a. Erneuerung aus der Bibel, in Umgang mit Luther, 39-58. Tübingen: Mohr.

--- 1983b. Die Toleranz Gottes und die Toleranz der Vernunft, in Umgang mit Luther, 101-130. Tübingen: Mohr.

--. 1983c. Theologisches Verantworten des Politischen: Luthers Unterrichtung der Gewissen heute bedacht, in Umgang mit Luther, 164-201. Tübingen: Mohr.

Fowler, S 1991. National identity and the renewal of democracy. Potchefstroom: IRS. (Reeks F1 no 277/278).

Graf, F W 1990a. Bedingungen der Toleranz: Protestantismus und multikulturelle Gesellschaft. EvKomm 23, 10-13.

--- 1990b. Königsherrschaft Christi in der Demokratie: Karl Barth und die deutsche Nachkriegspolitik. EvKomm 23, 735-738.

Habermas, J 1985. Ziviler Ungehorsam - Testfall für den demokratischen Rechtsstaat, in Die neue Unübersichtlichkeit. Frankfurt: Suhrkamp.

Hartmann, K 1981. Politische Philosophie. Freiburg: Karl Alber.

Hobbes, T 1839. De cive, in Opera philosophica quae latine scripsit omnia, vol 2. Ed $\mathrm{G}$ Molesworth. London.

Honecker, M 1978. Das Recht des Menschen: Einführung in die evangelische Sozialethik. Gütersloh: Gerd Mohn. (Taschenbücher Siebenstern 290.)

-.. 1982a. Prophetie im Widerspruch zur Ethik: Geschichtsdeutung ist immer mehrdeutig. EvKomm 15, 65-67.

-.. 1982b. Die Hoffnung des Glaubens und die Verantwortung der Welt: Überlegungen zum Verhältnis von Eschatologie und Ethik, in Verifikationen: Festschrift für Gerhard Ebeling zum 70. Geburtstag, hg v E Jüngel. Tübingen: Mohr.

Hultgren, A J 1976. Reflections on Romans 13:1-7: Submission to governing authorities. Dialog 15, 263-269.

Jüngel, E 1985. Glaube und Demokratie. EvKomm 18, 707-709.

Kaiser, O 1985. Gerechtigkeit und Heil bei den israelitischen Propheten und griechischen Denkern des 8.- 6. Jahrhunderts, in Der Mensch unter dem Schicksal. Studien zur Geschichte, Theologie und Gegenwartshedeurung der Weisheit. Berlin: De Gruyter. 
Kant, I 1983. Kritik der reinen Vernunft, in Werke, Bd 2. 4. Aufl. Darmstadt: Wissenschaftliche Buchgesellschaft.

Käsemann, E 1974. An die Römer. 12. Aufl. Göttingen: Vandenhoeck. (KEK.)

Kraus, H J 1972. Psalmen. 2. Teilband. 4. Aufl. Neukirchen-Vluyn: Neukirchener Verlag. (BKAT Band XV/2.)

-.- 1979. Theologie der Psalmen. Neukirchen-Vluyn: Neukirchener Verlag. (BKAT XV/3.)

Lehmann, P 1987. Christologie und Politik: Eine theologische Hermeneutik des Politischen. Göttingen: Vandenhoeck.

Lohse, B 1974. Gewissen und Autorität bei Luther. KuD 20, 1-22.

Lohse, E 1988. Theologische Ethik des Neuen Testaments. Stuttgart: Kohlhammer. (Theologische Wissenschaft 5,2.)

Luther, M 1883vv. WA = Kritische Gesamtausgabe. (Weimarer Ausgabe.)

Manenschijn, G s a. Het geweten in verzet tegen de wereldlijke macht, in Veenhof J, Vos J S \& Werkman LA (reds), Het rijk Gods en de aardse macht: Theologische visies op de verhouding van geloof en politiek. Kampen: Kok.

Michel, D 1988. Qohelet. Darmstadt: Wissenschaftliche Buchgesellschaft. (Erträge der Forschung Band 258.)

Moltmann, J 1976. Der gekreuzigte Gott: Das Kreuz Christi als Grund und Kritik christlicher Theologie. 3. Aufl. München: Kaiser.

Pannenberg, W 1983. Anthropologie in theologischer Perspektive. Göttingen: Vandenhoeck.

--- 1984. Die Erfahrung der Abwesenheit Gottes in der modernen Theologie, in Pannenberg, W (Hrsg), Die Erfahrung der Abwesenheit Gottes in der modernen Kultur. Göttingen: Vandenhoeck.

Pelser, G M M 1986. Die Christen en die owerheid volgens Romeine 13:1-7. HTS 42, 515-533.

Rendtorff, T 1981. Ethik: Grundelemente, Methodologie und Konkretionen einer ethischen Theologie, Band 2. Stuttgart: Kohlhammer. (Theologische Wissenschaft 13.)

Reuter, H R 1990. Gerechtigkeit: Bemerkungen zur theologischen Dimension eines sozialethischen Grundbegriffs. EvTh 50, 172-188.

Rohrmoser, G 1989. Religion und Politik in der Krise der Moderne. Graz: Styria.

Ruokanen, M 1988. Augustin und Luther über die Theologie der Politik. KuD 34, $22-41$.

Sauter, G 1984. Was heißt 'Evangelische Theologie?' EvTh 44, 112-136.

-.- 1985. 'Leiden' und 'Handeln'. EvTh 45, 435-458.

Schlier, H 1979. Der Römerbrief. 2. Aufl. Freiburg: Herder. (HThK.) 
Schrage, W 1982. Ethik des Neuen Testaments. Göttingen: Vandenhoeck. (Grundrisse zum Neuen Testaments. NTD Ergänzungsreihe 4.)

Schwartländer, J 1977. Freiheit im weltanschaulichen Pluralismus: Zum Problem der Menschenrechte, in Simon, J (Hrsg), Freiheit: Theoretische und praktische Aspekte des Problems, 205-238. Freiburg: Karl Alber.

The Kairos document 1985. Challenge to the church: A theological comment on the political crisis in South Africa. Braamfontein.

The road to Damascus 1989. Kairos and conversion. Johannesburg: Skotaville.

Trillhaas, W 1970. Ethik. 3. Aufl. Berlin: De Gruyter.

Van Heerden, T J 1982. Inleiding tot die polisiekunde. Studiegids in Departement Kriminologie. Pretoria: Unisa.

Van Wyk, 1 W C 1987. Das Theodizeeproblem als Orientierungspunkt der kirchenpolitischen und theologischen Streitfragen: Eine Auseinandersetzung mit Jürgen Moltmann. DD-proefskrif, Universiteit van Pretoria.

-- 1990. Dié skuldbelydenis 'n vrug van moralisme. Die Henormer 15 Desember, 5.

Villa-Vicencio, C 1990. Civil disobedience and beyond: Law, resistance and religion in South Africa. Grand Rapids: Eerdmans.

Von Rad, G 1969. Theologie des Alten Testaments, Band 1. München: Kaiser.

--- 1970. Weisheit in Israel. Neukirchen-Vluyn: Neukirchener Verlag.

Wendland, H-D 1975. Ethik des Neuen Testaments. 2. Aufl. Göttingen: Vandenhoeck. (Grundrisse zum Neuen Testaments NTD Ergänzungsreihe 4.)

Wilckens, U 1982. Der Brief an die Römer. 3. Teilband. Zürich: Benziger. (EKK.) 